\title{
INFLUENCE OF SOME LEGUMINOUS TREES AND ARBUSCULAR MYCORRHIZAL FUNGI ON THE PHYSIOLOGY AND YIELD OF DIOSCOREA ROTUNDATA -POIR
}

\author{
AFOLAYAN, Ezekiel Taiwo \\ Federal College of Education, Abeokuta, Ogun State, Nigeria \\ Correspondence: tailayo021204@yahoo.com
}

\section{Abstract}

This work compares the physiological and yield characteristics of white yam (Dioscorea rotundata - Poir) under Arbuscular mycorrhizal fungi (AMF) inoculation, green manures of Gliricidia sepium, Leucaena leucocephala and other soil amendments. The experiment was conducted on the plot of land that had been overcropped, located at the back of the male Hostel, Federal College of Education, Abeokuta, Ogun State, Nigeria. The land was cleared and heaped at Imx Im apart. The experimental design employed was a complete randomized design in 5 replicates. The treatments were Glomus deserticola (GD), Glomus fasciculatum (GF), Gliricidia sepium (GS), Leucaena leucocephala (LL), Poultry manure (PM) and NPK fertilizers. Soils were dug from the heaps, $20 \mathrm{~g}$ of the inoculums of $A M F(G D / G F)$ were poured into the dug hole, seeds were laid on it and covered with soil (for GD \& GF treatments). Others were applied at one week after sprouting. Growth and yield Parameters were determined at harvest while relative water and chlorophyll contents were measured forth nightly from 10 weeks after treatment. Data obtained were subjected to ANOVA while means were separated by Duncan multiple range test at P> 0.05. Results showed that growth, yield and physiological characters were enhanced in $G D, G D+G F, G S$ and $P M$ treated plants more than in inorganic fertilizers treated plants. There was a positive significant relationship between white yam's growth, physiology and tuber yield. The study justifies the use of plant/animal manures and Arbuscular mycorrhizal fungi in place of inorganic fertilizers. 
bioRxiv preprint doi: https://doi.org/10.1101/2020.08.16.252908; this version posted August 17, 2020. The copyright holder for this preprint

(which was not certified by peer review) is the author/funder, who has granted bioRxiv a license to display the preprint in perpetuity. It is made available under aCC-BY-NC-ND 4.0 International license.

Keywords: Glomus fasciculatum, Glomus deserticola, white yam, Gliricidia sepium, yield. 


\section{INTRODUCTION}

White yam (Dioscorea rotundata - Poir) account for more than 200 dietary calories per person each day for an estimated 60 million people, especially in the yam producing countries like Nigeria, cote d'lvoire, Ghana and Cameroun (Zannou 2004; Zannou et al., (2007). Nigeria is the largest producer of yam (IITA, 1993; FAOSTAT, 1997; Aighewi et al., 2002). Economically yam provides job for both the farmers and the women who are marketers of the products. It is also rich in minerals sources of proteins, fats and vitamins, yam is used as a foaming agent in brewing industries, manufacturing of drugs, insecticides, flavours, fragrances, drinks and cosmetics. It also plays a significant role in the cultural life of rural communities in Benin, Igbo and Yoruba people of Nigeria (Onwueme, 1978; Yadana, 2009).

Arbuscular mycorrhizal (AM) fungi are mutually beneficial microorganisms that form a symbiotic association with the roots of vascular plants. The host Plants supply the Arbuscular Mycorrhizal fungi with sugars, while the fungi scavenge for immobile nutrients, e.g. Phosphorus. Mycorrhizal associations are functionally diverse both in effectiveness of the fungi as symbionts and in responsiveness of the plants in terms of total P uptake, growth, and/or reproduction (Read, 1998; Van der Heijden, and Sander, 2002; Jakobsen, 2002). Nitrogen and phosphorus deficiency are common in soils in the tropical and subtropical regions. This constitutes the main limiting nutrients in semi-arid and dry sub-humid Savanna (Bationo et al., 1992: Buerkert et al., 2001). Sequel to this development, farmers in these regions, especially in Africa, employed the use of inorganic fertilizers which may not be ecologically friendly.

Arbuscular mycorrhizal fungi are important and will be of tremendous assistance in sustainable agriculture in Africa because they improve plant water relations and thus increase the drought 
resistance of host plants (Allen and Allen, 1986; Naidoo, 1986), and they increase mineral uptake, which reduces the use of fertilizers. Improved plant water status and changes in water relations have been attributed to a wide variety of mechanisms (Smith, and Gianinazzi-Pearson. 1988; Davies et al., 1992).

Woody legumes are important for re-vegetation of ecosystems that have low amounts of available $\mathrm{N}$ and $\mathrm{P}$ in order to mitigate the effects of deforestation and maintain sustainable land-use management Danso et al., 1992). Leguminous trees are nitrogen fixing trees (NFTs) which helps in the restoration and/or maintenance of soil fertility. Some of the examples of these NTF are Gliricidia sepium and Leucaena leucocephala which are fast-growing perennial leguminous trees for soil nutrient enrichment, N2fixing capability and $\mathrm{P}$ assimilation and arbuscular mycorrhizal (AM) fungi which lives in the roots of plants as symbiotic organisms that helps the plants to absorb nutrients especially Phosphorus (Habte and Turk, 1991; Liyanage et al., 1994).

Macro and micronutrients together with some soil micro and macro organisms are both required for normal growth and development in plants. These, in their right proportion, are the major factors for enhanced yield and production of food. There is increase in plant metabolites as a result of the application of organic manure, this enhanced metabolic activities leading to improved growth characters. This increase in growth characteristics (i.e. stem, leaves, and roots) leads to higher photosynthetic activities and accumulation of higher photo assimilates (Yadana et al., 2009).

The use of organic fertilizers helps in preserving the ecosystem, maintain soil fertility by supplying of balanced nutrients, decomposition of harmful elements, improves soil structure, root development, and makes soil water available to plants roots and promote plants productivity. Organic manure increases soil mineral elements, crop productivity, plants' health and mineral utilization efficiency (Kaur et al., 2005; Murmu et al., 2013). Green manure of leguminous plants enhanced the 
stem diameter, leaf number, leaf area, pod length, weight and diameter of edible fresh Okra plants (Benjawan et al., 2007).

The objective of this work was to examine the growth and yield promoting abilities of arbuscular mycorrhizal fungi, green manure of Gliricidia sepium, Leucaena leucocephala and other soil amendments in an overcropped soil.

\section{MATERIALS AND METHODS}

This trial was carried out in 2017 and 2018 at the nutrients-depleted plot of land behind the male students' hall of residence at the Federal College of Education, Abeokuta, Ogun State, South-west Nigeria. The land was cleared, loosened and heaped at $1 \mathrm{~m}^{2} \times 1 \mathrm{~m}^{2}$ apart. Twenty grams (20 g) of mycorrhizal fungi inoculums (Glomus deserticola and Glomus fasciculatum) were measured into the dug hole on the heap and the seed yams $(450-500 \mathrm{~g})$ were placed on the inoculums before covering with the soil in AMF treatment plots. Seed yams were planted in the heap and mulched with $800 \mathrm{~g}$ Gliricidia sepium and Leucaena leucocephala as applicable. Poultry manure (80 g) and NPK fertilizer (40 g) was applied at one week after sprouting for poultry manure and NPK treatments. Staking was done with one stake per stand. Weeding and other agronomic practices were done as when due.

Plants performance was assessed through the following parameters:

(a). Shoot and Root weight: These were determined at harvest. Plants parts (shoot and roots) per plant were carefully collected and weighed.

(b). Tuber diameter and length: The diameter and length of the tubers per plant were determined using meter rule immediately after harvesting.

(c). Tuber weigh: At harvest, tubers of yams per plant were placed on the weighing balance for 
tuber's weight on the field.

(d). Chlorophyll content of leaves: This was done to determine the health of the plants. It was determined using pocket chlorophyll meter MO-SPC- SPAD 502 (Konica Minolta, USA) because it was done on the field. Leaves of each treatment were inserted into the machine while on the field, the chlorophyll content per plant is displayed on the screen of the chlorophyll meter.

(e). Relative water contents: Fresh leaves were collected from each treatment, each leaf was cut with cork borer into small discs, which were weighed and recorded (sample's Fresh Weight - W). The samples were then hydrated to full turgidity in distilled water for 4 hours under normal room conditions. These were removed from the water after 4 hours and the adhering moisture was quickly dried off with filter paper and immediately weighed (Turgid Weight - TW). Samples were then dried in an oven at $80^{\circ} \mathrm{C}$ for 24 hours, cooled in desiccators and later weighed (the dry weight- DW).

The following formula was used to determine the Relative Water Content (R W C).

$$
R W C(\%)=\frac{W-D W}{T W-D W} \times 100
$$

Where $\mathrm{W}=$ sample fresh weight; DW = sample dry weight; $\mathrm{TW}=$ sample turgid weight $($ Dingma, 2002).

Data obtained were subjected to statistical analysis using ANOVA (SPSS version 20), while treatments means were separated with Duncan multiple range test at 5\% level of probability.

\section{RESULTS AND DISCUSSION}

Chlorophyll and relative water contents of white yam under AMF, green manure of GS, LL and other soil amendments were determined and results were represented on 
figures 1and 2. Chlorophyll synthesis was enhanced by the application of GS, LL, GE, GM, PM and combined treatments of all the organic manures and arbuscular mycorrhizal fungi. A higher amount of Relative water content was observed in white yam treated with LL, PM, GF, GD, GS together with their combined treatments. There was a significant relationship between the water content and the chlorophyll contents synthesized in organic manure treated (GS, LL, GF, GD, PM in all organic manure treated plants (GS, LL, GD, GF, PM, GD+GF, GM+LL, GM+PM, GM+GS, LL+GF, LL+PM and LL+GS) when compared to the inorganic fertilizers and the untreated white yam. This may be due to increased absorption of water, $\mathrm{N}$, and $\mathrm{P}$ in AMF (GM and GF) inoculated plants and readily absorbable nutrients made available by the organic fertilizers which are responsible for normal metabolic activities in plants (Changxian et al., 2008). This result corroborates the report of some workers who reported an enhanced chlorophyll and relative water contents in white yams treated leguminous combined with AMF (Afolayan, 2017; Oyetunji, \& Afolayan, (2019).

Growth and yield characters of white yam treated with Arbuscular mycorrhizal fungi (AMF), green manure of Gliricidia sepium, Leucaena leucocephala and other soil amendment were correlated with each other and the results are presented in Table 3. It was observed that there was positive relationship between the shoot weight and the root weight $(r=0.655)$; tuber weight $(r=0.677)$; tuber diameter $(r=0.563)$ and tuber length (0.732) at $\mathrm{P}>0.05$ level of significance. Root weight had a significant and positive correlation with tuber weight $(\mathrm{r}=0.850)$ at $\mathrm{p}>0.05$ level of significance.

Furthermore, there was a positive relationship between tuber weight and relative water content $(r=0.812)$ and chlorophyll content $(r=0.845)$ at $p>0.05$ level of 
significant (Table 4).

Table 5 shows the effect of Arbuscular mycorrhizal fungi inoculation, green manure of Gliricidia sepium (GS), Leucaena leucocephala (LL) and other soil amendments on the growth and yield of white yam. The combined treatment of GS+LL enhanced the higher shoot weight (774.8 g) in white yam, while the untreated had the least (110.2 g). The result shows no significant difference between white yam treated with GS+LL and PM+GS; PM+NPK; GD+NPK; GM+GS and LL treated plants in their shoot weight. White yam treated with poultry manure (PM) had the highest root weight (19.2) which was significantly different from all the other treatments. Many workers opined that green manure (organic fertilizers) increase leaf number and area, shoot weight and productivity of plants (Kaur et al., 2005; Benjawan et al., 2007; Murmu et al., 2013).

It was observed that there was no significant difference in the root weight between GD; GS; and GD+PM treated plants. This is because green manure increases photosynthetic activities in plants, this will lead to higher photosynthates assimilated as tuber especially in yams (Bationo et al., 1992; Yadana et al., 2009). Tuber weight of white yam was enhanced by the combined treatment of plants and animal manure (PM+GS; LL+GS; LL+PM and GD+PM) (Buerkert et al., 2001). White yam inoculated with Glomus deserticola (GD) and the combined treatment of Glomus deserticola and Glomus fasciculatum (GD+GF) also enhanced tuber production. There was no significant difference between the tuber yield of GD and NPK treated plants. This result is similar to existing report, that growth and yield of plants were significantly enhanced by $\mathrm{AMF}$ and that the shoot dry weight of G. deserticola inoculated plants was almost twice of non-mycorrhizal plants (Changxian et al., 
(2008).

\section{CONCLUSION}

African soil is faced with desertification, erosion, deforestation, excessive use of inorganic fertilizers which may be washed into nearby rivers, kill humus and soil microorganisms etc. Sustainable white yam production in this region is dependent on the good maintenance of the ecosystem. Bio-fertilizers and organic manure used in this trial enhanced white yam tubers production, this can conveniently replace NPK and other inorganic fertilizers.

\section{ACKNOWLEDGMENTS}

The author wishes to express his profound appreciation to the Tertiary Education Trust Fund (TETFUND) for the financial assistance.

\section{Competing interests}

The author declares no competing interests. 
Table1: Chlorophyll contents $\left(\mu \mathrm{mol} / \mathrm{m}^{2}\right)$ of Dioscorea rotundata treated with AMF, green manure of Gliricidia sepium, Leucaena leucocephala and other soil amendment under continuous cropping systems

\begin{tabular}{|c|c|c|c|c|c|}
\hline \multirow[t]{2}{*}{ Treatment } & \multicolumn{5}{|c|}{ Chlorophyll contents $\left(\mu \mathrm{mol} / \mathrm{m}^{2}\right)$} \\
\hline & $10 \mathrm{WAT}$ & $12 \mathrm{WAT}$ & $\begin{array}{l}14 \\
\text { WAT }\end{array}$ & $16 \mathrm{WAT}$ & $18 \mathrm{WAT}$ \\
\hline GD & $40.00^{\mathrm{h}}$ & $62.47^{\mathrm{ab}}$ & $65.23^{c}$ & $72.63^{\mathrm{ab}}$ & $78.73^{\mathrm{cd}}$ \\
\hline GF & $42.73^{\mathrm{fg}}$ & $61.27^{\mathrm{ab}}$ & $68.83^{\mathrm{b}}$ & $72.23^{\mathrm{ab}}$ & $77.37^{\mathrm{bcd}}$ \\
\hline GS & $43.77^{\mathrm{f}}$ & $64.03^{\mathrm{a}}$ & $70.07^{\mathrm{a}}$ & $76.83^{\mathrm{a}}$ & $76.87^{\mathrm{bcd}}$ \\
\hline LL & $50.53^{\mathrm{a}}$ & $59.77^{\mathrm{c}}$ & $64.57^{\mathrm{cd}}$ & $70.80^{\mathrm{ab}}$ & $79 .^{17 \mathrm{~cd}}$ \\
\hline NPK & $45.71^{\text {de }}$ & $60.35^{\mathrm{b}}$ & $66.30^{c}$ & $73.44^{\mathrm{ab}}$ & $64.60^{\mathrm{g}}$ \\
\hline PM & $38.24^{\mathrm{i}}$ & $46.40^{\mathrm{f}}$ & $60.71^{\mathrm{e}}$ & $71.62^{c}$ & $76.36^{\mathrm{bcd}}$ \\
\hline $\mathrm{GD}+\mathrm{GF}$ & $45.37^{\mathrm{de}}$ & $62.77^{\mathrm{ab}}$ & $69.67^{\mathrm{b}}$ & $74.40^{\mathrm{a}}$ & $81.17^{\mathrm{abc}}$ \\
\hline $\mathrm{GD}+\mathrm{LL}$ & $49.37^{\mathrm{ab}}$ & $65.67^{\mathrm{a}}$ & $69.97^{\mathrm{b}}$ & $75.27^{\mathrm{a}}$ & $85.70^{\mathrm{ab}}$ \\
\hline $\mathrm{GD}+\mathrm{PM}$ & $46.23^{\mathrm{d}}$ & $66.37^{\mathrm{a}}$ & $69.57^{\mathrm{b}}$ & $73.13^{\mathrm{ab}}$ & $87.80^{\mathrm{a}}$ \\
\hline GD+NPK & $44.73^{\mathrm{de}}$ & $62.27^{\mathrm{ab}}$ & $68.83^{b}$ & $77.33^{\mathrm{a}}$ & $84.50^{\mathrm{ab}}$ \\
\hline $\mathrm{GD}+\mathrm{GS}$ & $42.13^{\mathrm{fg}}$ & $61.70^{\mathrm{ab}}$ & $71.87^{\mathrm{a}}$ & $73.80^{\mathrm{ab}}$ & $78.53^{\mathrm{cd}}$ \\
\hline $\mathrm{LL}+\mathrm{GF}$ & $48.70^{c}$ & $53.63^{\mathrm{e}}$ & $60.33^{\mathrm{e}}$ & $76.17^{\mathrm{a}}$ & $75.37^{\mathrm{bcd}}$ \\
\hline $\mathrm{LL}+\mathrm{PM}$ & $47.67^{\mathrm{cd}}$ & $53.27^{\mathrm{e}}$ & $66.60^{c}$ & $72.37^{\mathrm{ab}}$ & $76.73^{b c d}$ \\
\hline $\mathrm{LL}+\mathrm{NPK}$ & $49.50^{\mathrm{ab}}$ & $52.67^{\mathrm{e}}$ & $60.03^{\mathrm{e}}$ & $67.60^{b}$ & $70.77^{\mathrm{f}}$ \\
\hline $\mathrm{LL}+\mathrm{GS}$ & $48.30^{c}$ & $56.80^{\mathrm{d}}$ & $68.33^{b}$ & $74.97^{\mathrm{a}}$ & $74.23^{\mathrm{e}}$ \\
\hline $\mathrm{PM}+\mathrm{NPK}$ & $40.57^{\mathrm{h}}$ & $54.50^{\mathrm{d}}$ & $63.23^{\mathrm{cd}}$ & $73.30^{\mathrm{ab}}$ & $75.43^{b c d}$ \\
\hline $\mathrm{PM}+\mathrm{GS}$ & $49.87^{\mathrm{ab}}$ & $59.93^{c}$ & $66.37^{c}$ & $71.00^{\mathrm{c}}$ & $81.03^{a b c}$ \\
\hline CTRL & $16.67^{j}$ & $39.63^{\mathrm{g}}$ & $41.23^{\mathrm{f}}$ & $44.90^{\mathrm{d}}$ & $40.97^{\mathrm{h}}$ \\
\hline
\end{tabular}

Values are means of five replicates. Means with the same letter in a column are not significantly different (DMRT at p $<0.05)$. AMF =Arbuscular mycorrhizal fungi; PM = Poultry manure; NPK= Nitrogen-PhosphorusPotassium fertilizers; GS = Green Manure of Gliricidia sepium; LL: Leucaena leucocephala; $\quad$ GD: Glomus deserticola; GF; Glomus fasciculatum and CTRL= untreated plants. 
Table 2: $\quad$ Percentage RWC of white Yam treated with AMF, green manure of G. sepium, Leucaena leucocephala and other soil amendment on an overcropped soil

\begin{tabular}{|c|c|c|c|c|c|}
\hline \multirow[t]{2}{*}{ Treatment } & \multicolumn{5}{|c|}{ Relative water contents (\%) } \\
\hline & $8 \mathrm{WAT}$ & $10 \mathrm{WAT}$ & 12 WAT & 14 WAT & $16 \mathrm{WAT}$ \\
\hline GM & $46.60^{c}$ & $57.70^{\mathrm{f}}$ & $64.10^{f}$ & $74.00^{\mathrm{b}}$ & 78.10ab \\
\hline GE & $49.77 \mathrm{ab}$ & $59.87 d$ & $73.13^{b}$ & $75.13^{b}$ & $78.93 \mathrm{ab}$ \\
\hline GS & $52.07 a$ & $62.27 c$ & $72.23^{\mathrm{bc}}$ & $79.43^{\mathrm{a}}$ & $79.83^{\mathrm{ab}}$ \\
\hline LL & $53.00^{a}$ & $58.97 \mathrm{e}$ & $61.60 \mathrm{~g}$ & $75.20^{\mathrm{b}}$ & $76.67 \mathrm{c}$ \\
\hline NPK & $47.37 \mathrm{c}$ & $54.73 \mathrm{~g}$ & $50.20^{\mathrm{h}}$ & 62.17hi & $74.53^{\mathrm{d}}$ \\
\hline PM & $52.70^{a}$ & $59.43^{\mathrm{d}}$ & $69.93^{c}$ & $75.20^{\mathrm{b}}$ & 78.07ab \\
\hline $\mathrm{GM}+\mathrm{GE}$ & $50.73^{\mathrm{ab}}$ & $60.43^{\mathrm{d}}$ & $70.93^{c}$ & $73.70^{c}$ & $75.13^{d}$ \\
\hline GM + LL & $49.80^{\mathrm{ab}}$ & $52.77 \mathrm{~h}$ & $66.33^{d}$ & $71.43^{\mathrm{ab}}$ & 79.07ab \\
\hline GM+ PM & $45.43^{d}$ & $57.67 \mathrm{f}$ & $64.57 \mathrm{f}$ & $68.43^{d}$ & $70.27 \mathrm{f}$ \\
\hline $\mathrm{GM}+\mathrm{NPK}$ & $50.73^{\mathrm{ab}}$ & $57.90^{\mathrm{f}}$ & $66.23^{\mathrm{d}}$ & $62.03^{\mathrm{ef}}$ & $58.77 \mathrm{~g}$ \\
\hline $\mathrm{GM}+\mathrm{GS}$ & $52.67^{a}$ & $64.63^{b}$ & $71.93^{\mathrm{bc}}$ & $73.00^{c}$ & $73.10 \mathrm{e}$ \\
\hline $\mathrm{LL}+\mathrm{GE}$ & $47.93^{c}$ & $59.43^{d}$ & $75.93^{a}$ & $75.00^{\mathrm{b}}$ & $82.80^{a}$ \\
\hline $\mathrm{LL}+\mathrm{PM}$ & $53.70^{a}$ & $66.50^{a}$ & $75.67 a$ & $76.20^{b}$ & $76.80^{c}$ \\
\hline $\mathrm{LL}+\mathrm{NPK}$ & $43.83^{e}$ & $46.67^{i}$ & $50.80^{\mathrm{h}}$ & $67.07 \mathrm{~d}$ & 73.30e \\
\hline $\mathrm{LL}+\mathrm{GS}$ & $51.33^{\mathrm{ab}}$ & $63.93 \mathrm{bc}$ & $65.33^{e}$ & $61.33^{f}$ & $77.50^{c}$ \\
\hline $\mathrm{PM}+\mathrm{NPK}$ & $45.83^{\mathrm{d}}$ & $57.13^{f}$ & $67.80^{\mathrm{d}}$ & $63.63^{e}$ & $70.47^{f}$ \\
\hline $\mathrm{PM}+\mathrm{GS}$ & $50.50^{\mathrm{ab}}$ & $61.17 \mathrm{c}$ & $65.67 \mathrm{e}$ & $67.30^{\mathrm{d}}$ & $80.50^{\mathrm{b}}$ \\
\hline CTRL & $30.3^{f}$ & $32.50 \mathrm{j}$ & $35.23^{\mathrm{i}}$ & $35.67 \mathrm{~g}$ & $38.17 \mathrm{~h}$ \\
\hline
\end{tabular}

Values are means of five replicates. Means with the same letter in a column are not significantly different (DMRT at $\mathrm{p}<0.05)$. AMF =Arbuscular mycorrhizal fungi; $\mathrm{PM}=$ Poultry manure; NPK= Nitrogen-PhosphorusPotassium fertilizers; GS = Green Manure of Gliricidia sepium; LL: Leucaena leucocephala; GD: Glomus deserticola; GF; Glomus fasciculatum and CTRL= untreated plants. 
Table 3: Correlation coefficient between the growth and yield characters of white yam treated with green manure of Gliricidia sepium, Leucaena leucocephala, AMF and other soil amendments

\begin{tabular}{lllll}
\hline Parameters & $\begin{array}{l}\text { Shoot } \\
\text { weight }\end{array}$ & Root weight & $\begin{array}{l}\text { Tuber } \\
\text { weight }\end{array}$ & Tuber Width \\
\hline Shoot weight & & & & \\
Root weight & $0.655^{* *}$ & & \\
Tuber weight & $0.677^{* *}$ & $0.850^{* *}$ & & \\
Tuber width & $0.563^{* *}$ & $0.870^{* *}$ & $0.779^{* *}$ & \\
Tuber length & $0.732^{* *}$ & $0.843^{* *}$ & $0.748^{* *}$ & $0.839^{* *}$ \\
\hline
\end{tabular}

**. Correlation is significant at the 0.01 level (2-tailed). 
Table 4: The relationship between the yield and physiological characters of white yam treated with green manure of Gliricidia sepium, Leucaena leucocephala, AMF and other soil amendments

\begin{tabular}{lclcc}
\hline Parameters & $\begin{array}{c}\text { Tuber } \\
\text { Weight } \\
\text { (g/plant) }\end{array}$ & $\begin{array}{l}\text { Tuber } \\
\text { Width } \\
\text { plant) }\end{array}$ & $\begin{array}{c}\text { Tuber } \\
\text { (per } \begin{array}{l}\text { length } \\
\text { plant) }\end{array}\end{array}$ & $\begin{array}{l}\text { RWC(\%) } \\
\text { plant) }\end{array}$ \\
\hline $\begin{array}{l}\text { Tuber weight (per } \\
\text { plant) } \\
\text { Tuber width (per plant) }\end{array}$ & $0.779^{* *}$ & & \\
$\begin{array}{l}\text { Tuber length (per plant) } \\
\text { Relative Water Content } \\
\text { of Leaves }\end{array}$ & $0.748^{* *}$ & $0.839^{* *}$ & & \\
$\begin{array}{l}\text { Chlorophyll contents of } \\
\text { leaves }\end{array}$ & $0.812^{* *}$ & $0.840^{* *}$ & $0.852^{* *}$ & \\
\hline
\end{tabular}

**. Correlation is significant at the 0.01 level (2-tailed). 
Table 5: Effects of green manure, Arbuscular mycorrhizal fungi inoculations and other soil amendments on the growth and yield of white yam

\begin{tabular}{|l|l|l|l|}
\hline Treatment & Shoot weight $(\mathbf{g})$ & Root weight $(\mathbf{g})$ & Tuber weight $(\mathbf{k g})$ \\
\hline GD & $422.31^{\mathrm{d}}$ & $19.20^{\mathrm{b}}$ & $3.5^{\mathrm{e}}$ \\
\hline GF & $391.44^{\mathrm{e}}$ & $16.70^{\mathrm{e}}$ & $2.9^{\mathrm{f}}$ \\
\hline GS & $757.00^{\mathrm{a}}$ & $19.50^{\mathrm{b}}$ & $2.4^{\mathrm{g}}$ \\
\hline LL & $749.61^{\mathrm{a}}$ & $16.31^{\mathrm{e}}$ & $3.1^{\mathrm{f}}$ \\
\hline NPK & $658.03^{\mathrm{b}}$ & $17.02^{\mathrm{d}}$ & $3.6^{\mathrm{e}}$ \\
\hline PM & $733.60^{\mathrm{a}}$ & $20.20^{\mathrm{a}}$ & $3.8^{\mathrm{d}}$ \\
\hline GD+GF & $421.71^{\mathrm{d}}$ & $17.21^{\mathrm{d}}$ & $4.5^{\mathrm{b}}$ \\
\hline GD + LL & $372.26^{\mathrm{e}}$ & $18.14^{\mathrm{c}}$ & $3.5^{\mathrm{d}}$ \\
\hline GD+ PM & $681.60^{\mathrm{b}}$ & $19.00^{\mathrm{b}}$ & $4.3^{\mathrm{c}}$ \\
\hline GD+NPK & $719.33^{\mathrm{a}}$ & $17.20^{\mathrm{d}}$ & $4.6^{\mathrm{b}}$ \\
\hline GD+GS & $746.21^{\mathrm{a}}$ & $17.02^{\mathrm{d}}$ & $3.9^{\mathrm{d}}$ \\
\hline LL+GF & $551030^{\mathrm{c}}$ & $18.22^{\mathrm{c}}$ & $3.0^{\mathrm{f}}$ \\
\hline LL+PM & $536.00^{\mathrm{c}}$ & $16.70^{\mathrm{e}}$ & $4.1^{\mathrm{c}}$ \\
\hline LL+NPK & $680.05^{\mathrm{b}}$ & $16.83^{\mathrm{e}}$ & $3.7^{\mathrm{d}}$ \\
\hline LL+GS & $764.83^{\mathrm{a}}$ & $18.32^{\mathrm{c}}$ & $4.7^{\mathrm{b}}$ \\
\hline PM+NPK & $739.63^{\mathrm{a}}$ & $18.00^{\mathrm{c}}$ & $4.7^{\mathrm{b}}$ \\
\hline PM+GS & $760.41^{\mathrm{a}}$ & $18.91^{\mathrm{c}}$ & $5.5^{\mathrm{a}}$ \\
\hline CTRL & $180.00^{\mathrm{f}}$ & $11.00^{\mathrm{f}}$ & $1.6^{\mathrm{h}}$ \\
\hline
\end{tabular}

Values are means of five replicates. Means with the same letter in a column are not significantly different (DMRT at $\mathrm{p}<0.05)$ AMF: Arbuscular mycorrhizal fungi; PM: Poultry manure; NPK: Nitrogen-Phosphoruspotassium fertilizers; GS: Green Manure of Gliricidia sepium; LL: Leucaena leucocephala; GF: Glomus fasciculatum; GD Glomus deserticola and CTRL $=$ untreated plants.

\section{REFERENCES}

Afolayan, E. T. (2017). Effects of Green Manure of Gliricidiasepium (JacqKunth) and Leucaenaleucocephala (Lam De Wit), Arbuscular Mycorrhizal Fungi, and soil Amendments on the Physiological and Yield Characters of White yam (Dioscorea rotundata - Poir) under Nutrient-depleted Soil. International Journal of Innovative Research and Development 6(12).

Aighewi, B. A., Akoroda, M.O. \& Asiedu, R. (2002). Seed yam (Dioscorea rotundata Poir)production, storage and quality in selected yam zones of Nigeria. African journal of root and tuber crops 5(1): 20-23.

Allen, E. B., and M. F. Allen. 1986. Water relations of xeric grasses in the field: interactions of mycorrhizas and competition. New Phytol. 104:559-571.

Benjawan, C., Chutichudet, P., and S. Kaewsit. (2007). Effects of green manures on growth, yield and quality of green okra (Abelmoschus esculentus L.) Har Lium Cultivar. Pak J Biol Sci.10(7):1028-35

Bationo, A., Christianson, B.C., Baethgen, W.E., Mokwunye, A.U. (1992). A farm-level evaluation of nitrogen and phosphorus fertiliser use and planting density for pearl millet production in Niger. Fert. Res. 31: 175-184. 
Buerkert, A., Batanio, A., Piepho, H. P. (2001). Efficient phosphorus application strategies for increased crop production in Sub-Saharan West Africa. Field Crop Res. 72: 1-15.

Changxian, W., Xiaolin, L., Jianchao, Z., Guiqiang, W. and Yangyi, D. (2008). Effects of Arbuscular Mycorrhizal Fungi on Growth and Yield of Cucumber Plants. Communications in Soil Science and Plant Analysis Volume 39, Issue 3-4

Danso, S.K.A., Bowen, G.D., Sanginga, N. (1992). Biological nitrogen fixation in trees in agroecosystems. Plant Soil 141:177-196. 
Davies, F. T., J. R. Potter, and R. G. Linderman. 1992. Mycorrhiza and repeated drought exposure affect drought resistance and extraradical hyphae development of pepper plants independent of plant size and nutrient content. J. Plant Physiol. 139:289-294.

Dingma, S. L. 2002. Physical hydrology. Upper saddle River, N. J. Prentice hall. 2: 324-330.

FAOSTAT, 1997, CDROM

Habte, M., and Turk, D. (1991). Response of two species of Cassia and Gliricidia sepium to vesiculararbuscular mycorrhizal infection. Commun. Soil Sci. Plant Anal. 22: 17-18.

Hatwar GP, SU Gondane, SM Urkude and OV Gahukar, 2003. Effect of micronutrients on growth and yield of chili. Journal of Soils Crops. 13: 123-125

IITA, 1993. Yam Improvement at IITA, Ibadan`

Jakobsen, I, Smith, S. E. and Smith, F. A. (2002). Function and diversity of arbuscular mycorrhizae in carbon and mineral nutrition. In MGA van der Heijden, IR Sanders, eds, Mycorrhizal Ecology. Springer-Verlag, Berlin, pp 75-92

Kaur, K., Kapoor, K.K., Gupta, A.P. 2005. Impact of organic manure with and without mineral fertilizers on soil chemical biological properties under tropical conditions. Journal of Plant Nutrition and Soil Sci.168(1):117-122. 
Liyanage, M. S., Danso, S. K. A., Jayasundara, H. P. S. (1994). Biological nitrogen fixation in four Gliricidia sepium genotypes. Plant Soil. 161: 267-274.

Murmu K, Swain DK, Ghosh BC. 2013. Comparative assessment of conventional and organic nutrient management on crop growth and yield and soil fertility in tomato-sweet corn production system. Australian Journal of Crop Science. 7(11):1617-1626

Naidoo, G. 1986. Response of the mangrove Rhizophora mucronata L. to high salinities and low osmotic potentials. S. Afri. J. Bot. 52:124-128.

Onwueme, I. C. 1978. The tropical crops yams, Cassava sweet potatoes and Cocoyams. John Willey and Sons. New York. Pp 231-306 Manure (Sesbania rostrata) on the Growth and Yield of Rice. J Fac Agr, Kyushu Univ. 54 (2): 313-319

Oyetunji, O. J. \& Afolayan, E. T. (2019). The Effects of Different Doses of Inorganic and Organic Fertilizers on the Physiology and Yield of White Yams' (Dioscorea Rotundata-Poir) Vine Cuttings under Continuous Cropping System. Sch Acad J Biosci, July, 2019; 7(7)

Read, D. J. (1998). Plants on the web. Nature 396: 22-23

Smith, S. E., and V. Gianinazzi-Pearson. 1988. Physiological interactions between symbionts in vesicular-arbuscular mycorrhizal plants. Annu. Rev. Plant Physiol. 39:221-244.

Van der Heijden, M. G. A. and Sanders, I. R. editors (2002) Mycorrhizal Ecology. Springer-Verlag, Berlin

Yadana, K.L, Aung, K.M, Takeo Y, and Kazuo O, 2009. The Effects of Green maintaining yam and cowpea diversity in Benin. Int. J. Agric. Sust. 5(23):140-160.

Zannou, A., Ahanchédé, A., Struik, P.C., Richards, P., Zoundjihékpon, J., Tossou, R., Vodouhè, S. (2004). Yam and cowpea diversity management by farmers in the Guinea Sudan transition zone of Benin, NJAS 52(3-4):393-420.

Zannou, A., Tossou. R.C., Vodouhè. S., Richards. P., Struik. P. C., Zoundjihékpon, J., Ahanchédé, A., Agbo, V. (2007). Socio-cultural factors influencing and maintaining yam and cowpea diversity in Benin. Int. J. Agric. Sust.5(2-3):140160. 